Article

\title{
Coal-Degrading Bacteria Display Characteristics Typical of Plant Growth Promoting Rhizobacteria
}

\author{
Yinka Titilawo, Wiya L. Masudi, Jacob T. Olawale, Lerato M. Sekhohola-Dlamini $\mathbb{D}^{\text {and }}$ \\ A. Keith Cowan * (D) \\ Institute for Environmental Biotechnology, Rhodes University, Makhanda (Grahamstown) 6140, South Africa; \\ olayinkatemi@yahoo.co.uk (Y.T.); desamunya@gmail.com (W.L.M.); jaclawale@yahoo.com (J.T.O.); \\ sekhoholalerato0@gmail.com (L.M.S.-D.) \\ * Correspondence: a.cowan@ru.ac.za; Tel.: +27-46-603-7050
}

Received: 16 July 2020; Accepted: 26 August 2020; Published: 7 September 2020

check for updates

\begin{abstract}
Coal mining produces large quantities of discard that is stockpiled in large dumps. This stockpiled material, termed coal discard, poses an environmental threat emphasising the need for appropriate bioremediation. Here, metagenomic analysis of the $16 \mathrm{~S} \mathrm{rRNA}$ from ten coal-degrading strains previously isolated from coal slurry from discard dumps and from the rhizosphere of diesel-contaminated sites was used to establish genetic relatedness to known plant growth-promoting (PGP) bacteria in the NCBI database. Measurement of indole and ammonium production and solubilisation of $\mathrm{P}$ and $\mathrm{K}$ were used to screen bacteria for PGP characteristics. BLAST analysis revealed $\geq 99 \%$ homology of six isolates with reference PGP strains of Bacillus, Escherichia, Citrobacter, Serratia, Exiguobacterium and Microbacterium, while two strains showed $94 \%$ and $91 \%$ homology with Proteus. The most competent PGP strains were Proteus strain ECCN 20b, Proteus strain ECCN 23b and Serratia strain ECCN 24b isolated from diesel-contaminated soil. In response to L-trp supplementation, the concentration of indolic compounds (measured as indole-3-acetic acid) increased. Production of ammonium and solubilisation of insoluble P by these strains was also apparent. Only Serratia strain ECCN 24b was capable of solubilising insoluble K. Production of indoles increased following exposure to increasing aliquots of coal discard, suggesting no negative effect of this material on indole production by these coal-degrading bacterial isolates and that these bacteria may indeed possess PGP characteristics.
\end{abstract}

Keywords: coal discard; diesel-contaminated soil; discard dumps; biodegradation; phylogeny; plant growth-promoting bacteria

\section{Introduction}

Coal is a hydrophobic, highly porous and heterogeneous sedimentary rock mined for its energy content. It is classified according to the degree of aromaticity and ranked as either lignite, (sub)-bituminous coal or anthracite [1,2]. Physically, it is a material with a hardness scale of up to 3 Mohs for anthracite and classified as naturally recalcitrant [3,4]. Chemically, it is a complex mixture of aromatic, heterocyclic and aliphatic carbonaceous constituents, hence the high calorific value. In South Africa, residual coal and other materials of very low energy content are stockpiled in discard dumps. These discard dumps are numerous and a major source and contributor of pollutants (e.g., particulate matter, heavy metals, acid leachate, etc.) to the surrounding environment including the atmosphere and water bodies and, as a consequence, threaten the environment, human health and quality of life [5,6]. Not surprisingly, there is an urgent need for intervention [7]. Although attempts to stabilise these dumps by cultivation of cover crops does occur once mining is complete [8], a major oversight in developing rehabilitation strategies has been the apparent omission of biotic factors that underpin 
successful and sustainable revegetation. Recently, it was demonstrated that successful rehabilitation and vegetation of discard dumps can be achieved by exploiting the mutualism between coal-degrading microorganisms, mycorrhizal fungi and grasses [8].

Coal mining not only visibly disrupts the aesthetics of a landscape but also disrupts all of the soil components including soil horizons, structure, microorganisms and nutrient cycles that are crucial to sustaining a healthy ecosystem $[9,10]$. While a number of fungi show potential as rehabilitation biocatalysts and degrade coal into a soil-like humic-rich material [11-18], the only candidate enzymes identified and functionally characterised from coal-degrading fungi so far are laccase and esterase. Heterologous expression of Fusarium oxysporum laccase in Pichia pastoris was shown to depolymerise and liquefy solubilised brown coal with the release of humic and fulvic acids [18]. By comparison, the Penicillium decumbens P6 esterase depolymerised lignite resulting in increased formation of low-molecular mass humic acids with lower-percentage aromatic carbon but higher-percentage aliphatic carbon [19].

Bacterial conversion of coal, by comparison, has typically been to derive clean fuels and chemicals by developing environmentally sound energy-saving processes that do not cause secondary pollution $[20,21]$. While numerous studies on bacterial solubilisation and degradation of coal by different species of bacteria have been forthcoming, the underlying biochemical and molecular mechanisms involved are not yet fully understood [22,23]. Even so, numerous studies have revealed a role for bacteria in the degradative assimilation of petroleum hydrocarbons such as polynuclear aromatic hydrocarbons (PAHs), naphthalene, the monoaromatic hydrocarbons such as toluene and aliphatic hydrocarbons such as the $n$-alkanes [24,25]. These hydrocarbons are well represented in the naturally complex and highly aromatic coal structure and are also readily available in petroleum-contaminated soil environments [7]. Indeed, several recent extensive reviews on the subject have been published [26,27] and the potential for plant-bacteria partnerships in the remediation of hydrocarbon-contaminated soil has been proposed $[28,29]$. Bacterial conversion and utilisation of coal, though generally influenced by environmental conditions such as temperature and $\mathrm{pH}$, are dependent mainly on the type of coal and microorganism used [29] and similar to fungal biodegradation, the mechanisms seem to involve solubilisation, depolymerisation and degradative assimilation [7]. Bio-solubilisation is by alkaline substances, chelators and/or surfactants, whereas depolymerisation and liquefication likely entail oxidoreductases such as peroxidases and laccases, and hydrolases [30]. Under aerobic conditions, coal is oxidised by both biotic and abiotic processes to a weathered material rich in humic substances [31]. Under anaerobic conditions, a sequence of primary and secondary bacterial fermenters depolymerise and metabolise coal, providing a diverse range of short-chain organic acids and alcohols [32]. These low-molecular weight organic compounds serve as substrates for other consortia of microorganisms such as acetogens and methanogens [33-36]. In spite of many studies on the coal-degrading potential of bacteria, there remain limitations in phenotypic identification and the identification of other beneficial properties of these bacteria such as plant growth promotion. Modern molecular approaches, including analysis of PCR-amplified 16S rRNA gene sequences, have provided some insight into the identity, characterisation and phylogenetic classification of microorganisms capable of degrading and/or utilising coal [37-39]. To our knowledge, bacterial isolates from South African environments with coal-degrading capability have neither been extensively explored nor characterised genotypically.

An earlier bioprospecting study allowed for selected bacterial isolates with coal biodegradation potential to be characterised [40], but a more detailed biochemical and genetic analysis has yet to be described. Furthermore, screening of these coal-degrading bacteria for plant growth-promoting (PGP) characteristics has not previously been the subject of study. Defined as a class of microorganism that occupy the rhizosphere to promote plant growth, PGP bacteria are from diverse genera, display properties such as phytohormone production, siderophore and phosphate solubilisation activity, ACC deaminase activity and enhance plant productivity [41]. Typical uses are as inoculants for biostimulation, biocontrol and biofertilisation in agriculture and phytoremediation. In light of this 
background, the present study sought to establish, first, the genetic relatedness of these isolates to the diverse array of PGP bacteria contained in the established NCBI database and, second, screen these coal-degrading strains for characteristics typically displayed by PGP bacteria. An ability to mineralise phosphate and potassium and to produce ammonium and indoles (including the phytohormone, indole-3-acetic acid) was the criteria used in this study to determine bacterial PGP potential.

\section{Materials and Methods}

\subsection{Bacterial Strains}

Bacterial strains used in this study were previously isolated from coal slurry obtained from coal discard dumps at coal mines in Emalahleni $\left(26^{\circ} 0^{\prime} 0^{\prime \prime} \mathrm{S} ; 29^{\circ} 10^{\prime} 0^{\prime \prime} \mathrm{E}\right)$, Mpumalanga Province, South Africa, and slurries of material from diesel-contaminated sites (at a depth of $\sim 15 \mathrm{~cm}$ ) collected either from soil at mechanical workshops in Makhanda $\left(33^{\circ} 17^{\prime} 0^{\prime \prime} S ; 26^{\circ} 31^{\prime} 0^{\prime \prime}\right.$ E) or from old tractor engines at a farm in the Makana Local Municipality, Eastern Cape Province, South Africa (Table 1). Details of strain isolation, molecular characterisation, coal biodegrading activity and deposit into an international repository are recounted elsewhere [40].

Table 1. Bacterial strains with coal biodegrading activity isolated either from coal slurry (CS) or diesel-contaminated sites (DCS).

\begin{tabular}{|c|c|c|c|c|c|}
\hline Source & $\begin{array}{c}\text { Bacterial Isolates and Assigned } \\
\text { Strain Number }\end{array}$ & $\begin{array}{l}\text { Identity } \\
(\%)\end{array}$ & $\begin{array}{l}\text { Microbial Culture } \\
\text { Collection No. }\end{array}$ & $\begin{array}{c}\text { GenBank Accession } \\
\text { No. }\end{array}$ & $\begin{array}{l}\text { Length } \\
\text { (bp) }\end{array}$ \\
\hline CS & Citrobacter strain ECCN 19b & 99 & MCC0033 & KC700328 & 372 \\
\hline CS & Bacillus strain ECCN 26b & 99 & MCC0062 & KC700330 & 450 \\
\hline DCS & Bacillus strain ECCN 18b & 98 & MCC0034 & KC620473 & 560 \\
\hline DCS & Proteus strain ECCN 20b & 94 & MCC0027 & KC620475 & 553 \\
\hline DCS & Proteus strain ECCN 23b & 91 & MCC0022 & KC620478 & 439 \\
\hline DCS & Serratia strain ECCN $24 b$ & 99 & MCC0021 & KC620474 & 525 \\
\hline DCS & Bacillus strain ECCN 41b & 99 & MCC0039 & KC758162 & 392 \\
\hline
\end{tabular}

\subsection{Culture Conditions}

Coal-degrading bacterial isolates, listed in Table 1, were resurrected from glycerol stock by culture in nutrient broth (NB; $5 \mathrm{~g} \mathrm{~L}^{-1}$ peptone, $3 \mathrm{~g} \mathrm{~L}^{-1}$ yeast extract and $8 \mathrm{~g} \mathrm{~L}^{-1} \mathrm{NaCl}$ ) at $30^{\circ} \mathrm{C}$ on a rotary shaker $\left(120 \mathrm{rpm}\right.$ ) for $72 \mathrm{~h}$. Then, aliquots of NB were transferred to nutrient agar (NA; $5 \mathrm{~g} \mathrm{~L}^{-1}$ peptone, $3 \mathrm{~g} \mathrm{~L}^{-1}$ yeast extract and $8 \mathrm{~g} \mathrm{~L}^{-1} \mathrm{NaCl}$ and $15 \mathrm{~g} \mathrm{~L}^{-1}$ agar) plates and incubated at $30^{\circ} \mathrm{C}$ for 24 to $48 \mathrm{~h}$ to establish strain purity. Individual but distinct colonies were picked and inoculated into $40 \mathrm{~mL}$ of freshly prepared $\mathrm{NB}$, grown at $30^{\circ} \mathrm{C}$, and maintained in log phase.

\subsection{Extraction and PCR Amplification of Genomic DNA}

Extraction of total DNA was achieved using the ZR Fungal/Bacterial DNA Kit ${ }^{\mathrm{TM}}$ (Zymo Research, Irvine, CA, USA) according to the manufacturer's instructions. Target $16 \mathrm{~S}$ rRNA regions were amplified using DreamTaq ${ }^{\mathrm{TM}}$ DNA polymerase (Thermo Scientific ${ }^{\mathrm{TM}}$, Thermo Fisher Scientific, Waltham, MA, USA) with the bacterial universal primers 27F (5'-AGAGTTTGATCMTGGCTCAG-3') and 1492R (5'-CGGTTACCTTGTTACGACTT-3') as described by Lane et al. [42] and Turner et al. [43].

Sanger sequencing of the purified PCR products was carried out by Inqaba Biotechnical Industries (Pty) Ltd., Hatfield, South Africa using the PRISM ${ }^{\mathrm{TM}}$ Ready Reaction Dye Terminator Cycle sequencing kit using chain termination by the dideoxy-nucleotides methodology and electrophoresed on an ABI PRISM ${ }^{\circledR}$ 3500XL DNA Sequencer (Applied Biosystems, Foster City, CA, USA) following the manufacturer's instructions. Resultant chromatograms were analysed (Chromas version 2.6.6) as outlined in Technelysium [44], followed by pairwise alignment in BioEdit Sequence Alignment 
Editor, version 7.0.5.3 [45], and the resultant gene sequences compared with those already deposited (https://www.ncbi.nlm.nih.gov/).

\subsection{Phylogenetic Analysis}

Phylogenetic analysis using the $16 \mathrm{~S}$ rRNA sequences of the nine isolates and 32 reference nucleotide sequences for PGP bacteria from the NCBI GenBank database was conducted. Multiple alignment of nucleotide sequences was achieved using CLUSTALW as implemented in the BioEdit Sequence Alignment Editor. A phylogenetic tree was constructed from the neighbour-joining method using MEGA6 (Molecular Evolutionary Genetics Analysis Version 6.0) after calculating distances via the Jukes-Cantor method [46]. Trees were bootstrapped using 1000 replications.

\subsection{Screening for Plant Growth Promoting Characteristics}

\subsubsection{Ammonium Production}

Production of ammonium $\left(\mathrm{NH}_{4}{ }^{+}\right)$by the coal-degrading bacterial strains was determined using peptone water and Nessler's reagent $\left(\mathrm{HgI}_{4} \mathrm{~K}_{2}\right)$ as indicator. Peptone water containing $10 \mathrm{~g}$ of peptone (Sigma-Aldrich, Millipore Sigma, St. Louis, $\mathrm{MO}$ ) and $5 \mathrm{~g}$ of $\mathrm{NaCl}$ was prepared in $1 \mathrm{~L}$ distilled water and autoclaved at $121^{\circ} \mathrm{C}$ and $1.5 \mathrm{~kg} \mathrm{~cm}^{-2}$ for $15 \mathrm{~min}$. Nessler's reagent was prepared by suspending in $100 \mathrm{~mL}$ of distilled water, $10 \mathrm{~g}$ of $\mathrm{HgCl}_{2}, 7 \mathrm{~g}$ of $\mathrm{KI}$ and $16 \mathrm{~g}$ of $\mathrm{NaOH}$. The bacterial inoculants were added to flasks containing $40 \mathrm{~mL} \mathrm{PW}$ and incubated on a rotary shaker at $30{ }^{\circ} \mathrm{C}$ for $3 \mathrm{~d}$. After incubation, $4 \mathrm{~mL}$ of each culture was harvested by centrifugation (3920 $\mathrm{g}$ for $3 \mathrm{~min}$ ) and $\mathrm{NH}_{4}{ }^{+}$ concentration of the supernatant quantified spectrophotometrically. For colorimetric assay of $\mathrm{NH}_{4}{ }^{+}$, to $2 \mathrm{~mL}$ aliquots of supernatant from each sample was added $0.2 \mathrm{~mL}$ of Nessler's reagent and colour development allowed to proceed for $5 \mathrm{~min}$. Development of a brown colour was taken as a positive indicator of $\mathrm{NH}_{4}{ }^{+}$. For quantification, $1 \mathrm{~mL}$ was transferred to a cuvette and absorbance measured at $430 \mathrm{~nm}$ and results interpolated from a standard curve prepared using $\mathrm{NH}_{4} \mathrm{Cl}$ [47].

\subsubsection{Indole-3-Acetic Acid Production}

To determine the ability of the isolated bacterial strains to produce indole-3-acetic acid (IAA), NB was supplemented with L-trp and the concentration of indolic compounds produced by coal-degrading bacterial isolates determined using Salkowski's reagent [48-50].

Aliquots, equivalent to $40 \mu \mathrm{L}$ of bacterial suspension, were inoculated into NB supplemented with L-trp (at either $0,0.1,0.5$ and $1 \mathrm{~g} \mathrm{~L}^{-1}$ ) and incubated at $30^{\circ} \mathrm{C}$ on a rotary shaker $(120 \mathrm{rpm}$ ) for $72 \mathrm{~h}$. After incubation, $4 \mathrm{~mL}$ of each culture was sedimented by centrifugation (3920 $\mathrm{g}$ for $3 \mathrm{~min}$ ) and the cell-free supernatant used for colorimetric quantification of IAA which was carried out as follows: Two drops of $10 \mathrm{mM}$ of orthophosphoric acid and $4 \mathrm{~mL}$ of Salkowski's reagent $(50 \mathrm{~mL} 35 \%$ perchloric acid; and, $1.0 \mathrm{~mL} 0.5 \mathrm{M} \mathrm{FeCl}_{3}$ solution) were added to $2 \mathrm{~mL}$ cell-free supernatant, the mixture incubated at room temperature for $20 \mathrm{~min}$ and absorbance measured at $530 \mathrm{~nm}$. The quantity of indolic compounds (expressed as IAA equivalents) was determined by interpolation from a standard curve of authentic IAA (Sigma-Aldrich) and background subtracted to account for any interference from the culture medium.

\subsubsection{Solubilisation of Insoluble Phosphate and Potassium}

Phosphate and potassium solubilisation activity was initially determined using pour plates of either Pikovskayas agar (PVK) supplemented with tri-calcium phosphate $\left(\mathrm{Ca}_{3}\left(\mathrm{PO}_{4}\right)_{2}\right)$ or Aleksandrow medium (AM) containing $\mathrm{AlKO}_{6} \mathrm{Si}_{2}$ as the respective substrates. Modified PVK agar was prepared using $0.5 \mathrm{~g}$ of yeast extract, $10 \mathrm{~g}$ of glucose, $5 \mathrm{~g}$ of $\mathrm{Ca}_{3}\left(\mathrm{PO}_{4}\right)_{2}, 0.5 \mathrm{~g}$ of $\left(\mathrm{NH}_{4}\right)_{2} \mathrm{SO}_{4}, 0.2 \mathrm{~g}$ of KCl, $0.1 \mathrm{~g}$ of $\mathrm{MgSO}_{4}, 0.0001 \mathrm{~g}$ of $\mathrm{MnSO}_{4} \cdot \mathrm{H}_{2} \mathrm{O}, 0.0001 \mathrm{~g}$ of $\mathrm{FeSO}_{4} .7 \mathrm{H}_{2} \mathrm{O}$ and $15 \mathrm{~g}$ of agar in a total volume of $1 \mathrm{~L}$ of distilled water [46]. For the solubilisation of potassium by coal-degrading bacteria, $\mathrm{AM}$ was prepared containing $0.5 \mathrm{~g}$ of $\mathrm{MgSO}_{4} .7 \mathrm{H}_{2} \mathrm{O}, 0.1 \mathrm{~g}$ of $\mathrm{CaCO}_{3}, 2 \mathrm{~g}$ of $\mathrm{AlKO}_{6} \mathrm{Si}_{2}, 5 \mathrm{~g}$ of glucose, $0.005 \mathrm{~g}$ of 
$\mathrm{FeCl}_{3} \cdot 6 \mathrm{H}_{2} \mathrm{O}, 2 \mathrm{~g}$ of $\mathrm{Ca}_{3}\left(\mathrm{PO}_{4}\right)_{2}$ and $20 \mathrm{~g}$ of agar in $1 \mathrm{~L}$ of distilled water. An aliquot $(5 \mu \mathrm{L})$ of bacterial cell suspension was placed at 4 equidistant positions on either PVK or AM plates which were incubated at $30{ }^{\circ} \mathrm{C}$ for periods up to $14 \mathrm{~d}$. After incubation, $\mathrm{Ca}_{3}\left(\mathrm{PO}_{4}\right)_{2}$ and $\mathrm{AlKO}_{6} \mathrm{Si}_{2}$ solubilising activity was determined by observation of clear zones around active bacterial colonies [51,52]. Phosphate and potassium solubilising activity was quantified after inoculation of either liquid PVK or AM, prepared as above but without agar, with equal quantities of bacterial suspension from cells in exponential phase.

Following incubation at $30^{\circ} \mathrm{C}$ on a rotary shaker $(120 \mathrm{rpm})$, cell suspensions were sedimented by centrifugation $(3920 \times g$ for $3 \mathrm{~min})$ and the supernatant recovered for analysis. Ortho-phosphate concentration was determined spectrophotometrically using a Phosphate Test kit (Merck KGaA, Darmstadt, Germany) after $14 \mathrm{~d}$ while potassium concentration was measured after $9 \mathrm{~d}$ using sodium tetra-phenylborate as described by Pflaum and Howick [53]. The final concentration of phosphate and or potassium was determined by interpolation from standard curves prepared using ortho-phosphate and $\mathrm{KCl}$, respectively.

\subsection{Effect of Coal Discard on Production of IAA}

Geologically weathered coal was sourced and prepared to yield particles of approximately $0.2-0.5 \mathrm{~mm}$ in diameter and sterilised by freeze-thawing using liquid nitrogen as described earlier by Olawale et al. [40]. Aliquots of dry sterilised coal $(0-1 \mathrm{~g})$ were added directly to seed cultures prepared from stationery phase cells (i.e., $\mathrm{OD}_{600} 0.4$ after $3 \mathrm{~d}$ at $30{ }^{\circ} \mathrm{C}$ ) of the specified coal-degrading strains. Nutrient broth $(40 \mathrm{~mL})$ supplemented with L-trp and incubated at $30^{\circ} \mathrm{C}$ on a rotary shaker $(120 \mathrm{rpm})$ for $3 \mathrm{~d}$. Concentration of indolic compounds in solution was determined as described above after background subtraction to account for any coal-derived indoles.

\subsection{Statistical Analysis}

All data were computed using the statistical function in Sigma Plot version 11 (Systat Software Inc., San Jose, CA, USA). Where necessary, results were analysed by one-way analysis of variance and significant differences between measurements for each treatment were determined (Holm-Sidak method; $p<0.05)$. Data are presented as the mean of at least three determinations \pm standard error (SE).

\section{Results}

\subsection{Bacterial Genomes and Their Identification}

Partial 16S rRNA genomes of varying lengths ranging from 372 to $560 \mathrm{bp}$ were amplified and sequenced from each of the resurrected coal-degrading bacterial strains previously isolated from coal slurry and diesel-contaminated soil. The ten strains represent seven genera from three families. The most abundant were Bacilliaceae and Enterobacteriaceae, each with four strains and one Microbacteriaceae representative. Six isolates showed $99 \%$ sequence homology to reference strains that were confirmed as Exiguobacterium (KC620476), Serratia (KC620474), Citrobacter (KC700328), Bacillus (KC758162 and KC700330), Escherichia (KC700329) and Microbacterium (KC620477). One isolate, Bacillus (KC620473), showed $98 \%$ sequence homology, whereas KC620475 and KC620478 were $94 \%$ and $91 \%$ homologous to Proteus, respectively (Table 1). In this suite of previously identified coal-degrading bacterial strains, the most prevalent genus was Bacillus, accounting for 30\%. Strains of Proteus comprising $20 \%$ of the isolates were the next most abundant and were from diesel-contaminated soil. Remaining strains were confirmed to belong to the genera Escherichia, Citrobacter, Exiguobacterium, Serratia and Microbacterium.

\subsection{Nucleotide Sequence and Phylogenetic Analysis}

The coal-degrading bacterial isolates were further characterised following phylogenetic analysis of sequence relatedness to PGP reference strain sequences within GenBank. Together with the selected 32 reference sequences from GenBank, our sequences revealed six distinct but associated clusters. Eight (8) sequences clustered individually with their respective PGP bacteria relatives, with virtually 
all showing $100 \%$ bootstrap support at the corresponding major nodes (Figure 1). However, strain ECCN 19b (KC700328) which was from a coal environment, was the stand-out within a major cluster consisting of the genera Proteus, Serratia and Citrobacter. Other sequences from strains within the same cluster (KC620475 and KC620478) formed a distinct cluster with Proteus, and KC620474 clustered distinctly within the Serratia clade (Figure 1). Although most clusters in the phylogenetic tree showed high bootstrap values, strain ECCN 25b (KC700329) was excluded from the constructed phylogenetic tree as it did not match closely with any of the available GenBank PGP reference sequences in relation to source.

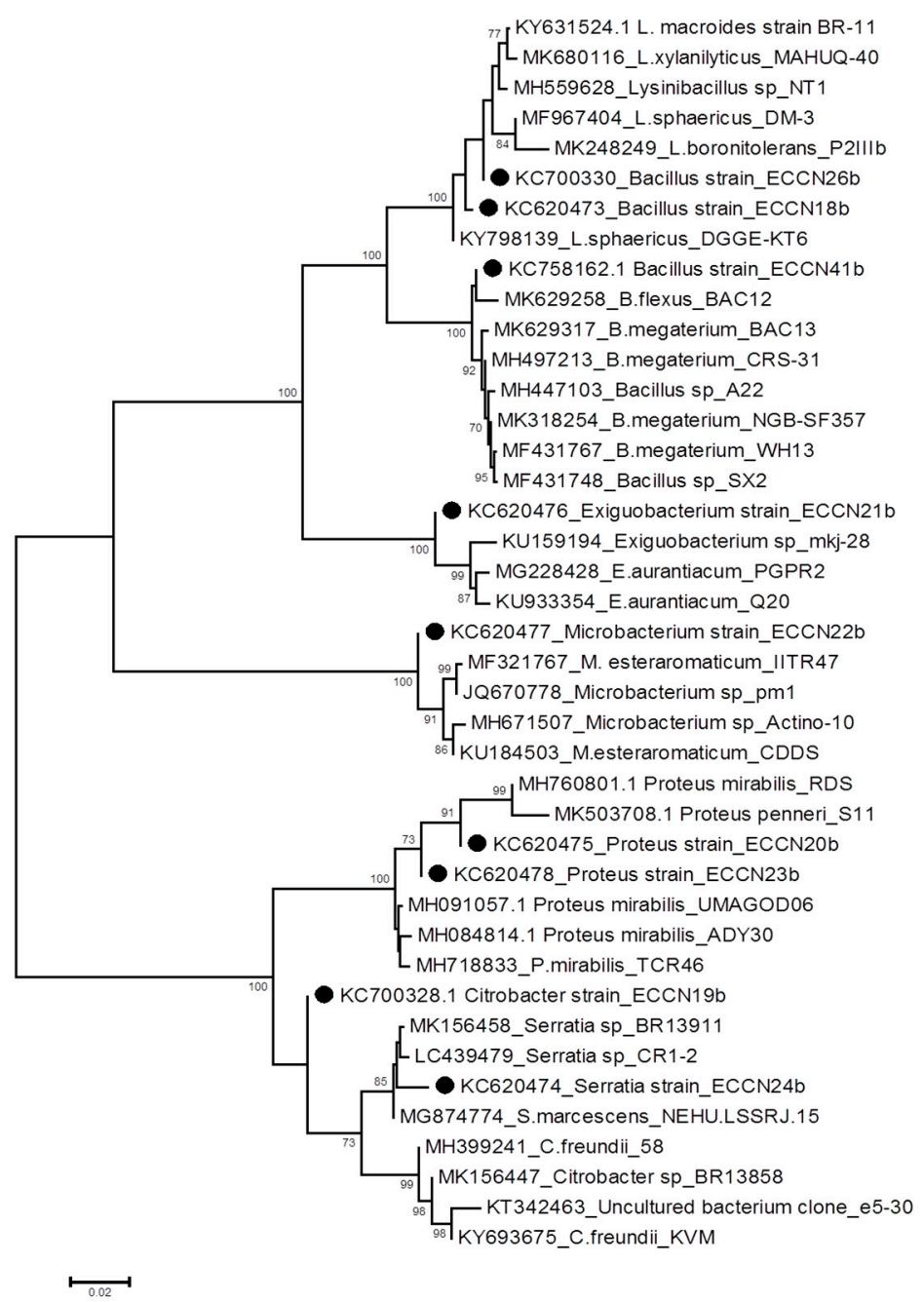

Figure 1. Phylogenetic tree showing relation between coal-degrading bacterial isolates $(\bullet)$ and reference PGP strains contained in the NCBI GenBank database. GenBank accession numbers and the corresponding taxonomic annotations are shown to the right of the strains. Bootstrap values of $\geq 70 \%$ are shown at the nodes.

\subsection{Plant Growth Promoting Characteristics}

Production of ammonium and indolic compounds (measured as IAA equivalents) by the coal-degrading bacterial strains Citrobacter ECCN 19b (KC700328), Proteus ECCN 20b (KC620475), Exiguobacterium ECCN 21b (KC620476), Microbacterium ECCN 22b (KC620477), Proteus ECCN 23b (KC620478), Serratia ECCN 24b (KC620474), Bacillus ECCN 26b (KC700330) and Bacillus ECCN 41b (KC758162) and solubilisation of $\mathrm{P}$ and K were determined spectrophotometrically and the results are shown in Figure 2. 


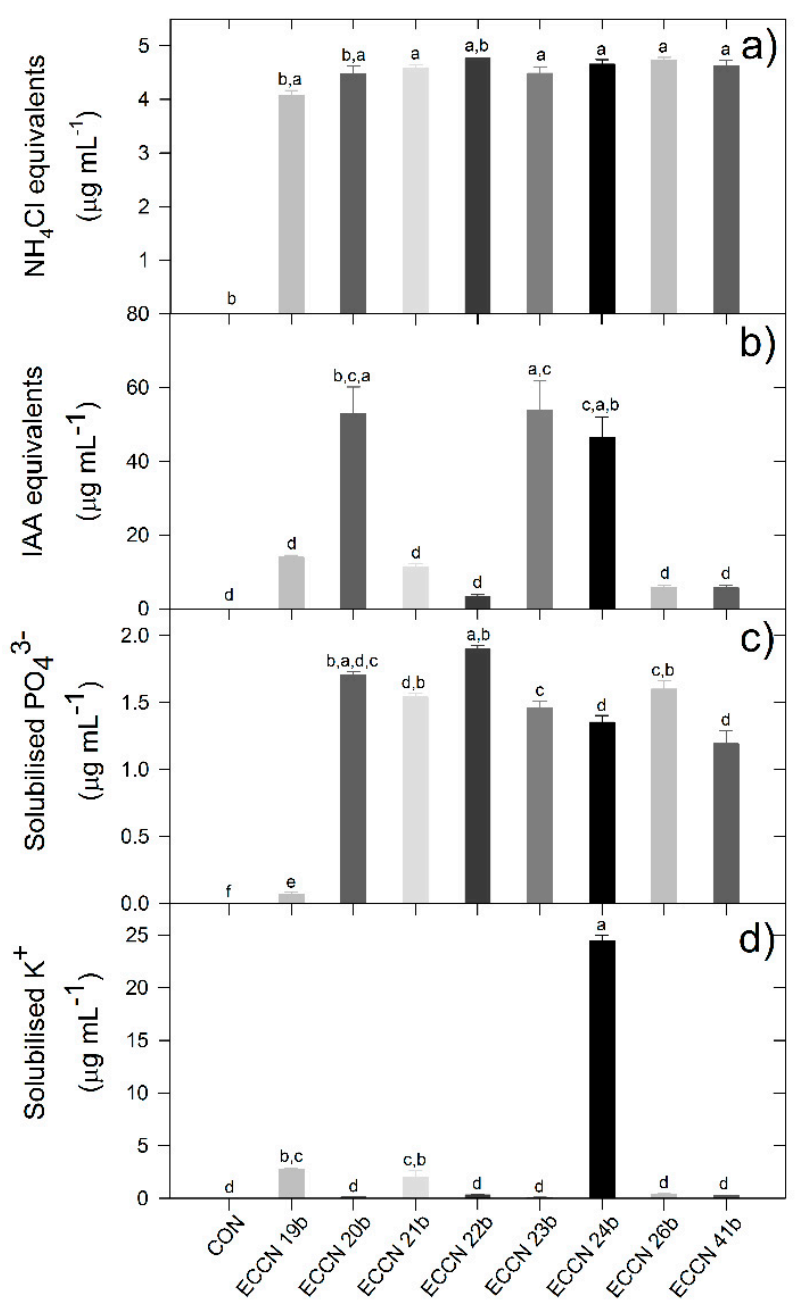

Figure 2. Screening of coal-degrading bacterial isolates for plant growth-promoting characteristics. Estimates of ammonium production (a), indole production (b), phosphate (c) and potassium solubilisation $(\mathbf{d})$ by these bacterial isolates in stationary phase (OD600 $=0.4$ at $30^{\circ} \mathrm{C}$ ) were determined spectrophotometrically. Results are expressed as the mean \pm S.E. Means denoted by a different letter indicate significant differences relative to a negative control $(p<0.05)$.

Ammonium production appeared to be a common trait of the coal-degrading bacterial strains evaluated for PGP characteristics (Figure 2a). Furthermore, whereas all of the strains produced above background levels of indolic compounds (Figure 2b), Proteus ECCN 20b, Proteus ECCN 23b and Serratia ECCN $24 b$ produced substantial quantities in response to L-trp $\left(0.5 \mathrm{~g} \mathrm{~L}^{-1}\right)$ supplementation (Figure $\left.2 b\right)$. Further, while it is accepted that mineral solubilisation can sometimes depend on the medium used [54], results from this study show that while phosphate solubilisation was low for these coal-degrading isolates, only one coal-degrading strain was unable to solubilise $\mathrm{Ca}_{3}\left(\mathrm{PO}_{4}\right)_{2}$ (Figure 2c). By comparison, Serratia strain ECCN 24b, and to a much lesser extent Citrobacter strain ECCN 19b and Exiguobacterium strain ECCN 21b, were the only coal-degrading bacteria able to solubilise potassium from $\mathrm{AlKO}_{6} \mathrm{Si}_{2}$ (Figure 2d).

Indole-3-acetic acid is a common, naturally occurring plant hormone of the auxin class, is derived from L-trp and is characteristically produced by many different PGP bacterial strains [55]. In an effort to gain further insight into the relationship between IAA production and the PGP potential of these coal-degrading bacterial strains, L-trp-activated IAA production by Proteus ECCN 20b, Proteus ECCN $23 \mathrm{~b}$ and Serratia ECCN 24b was examined, firstly, in response to increasing concentrations of this indole 
precursor and, secondly, following exposure of L-trp-supplemented cultures to increasing amounts of coal discard.

Results in Figure 3 clearly show that by increasing the concentration of L-trp supplied to cultures of Proteus ECCN 20b, Proteus ECCN 23b and Serratia ECCN 24b, production of indolic compounds including IAA, increased. Furthermore, these coal-degrading strains seemed equally competent in terms of indole production in response to activation by L-trp supplementation. Mean medium indolic compound concentration for the three strains increased from a mean minimum of $5.91 \mu \mathrm{g} \mathrm{mL}^{-1}$ in the absence of L-trp to a mean maximum of $83.49 \mu \mathrm{g} \mathrm{mL} \mathrm{m}^{-1}$ IAA (equivalents) in response to $1 \mathrm{~g} \mathrm{~L}^{-1} \mathrm{~L}$-trp supplementation. The almost linear increase in medium indolic compound concentration $\left(R^{2}=0.93\right)$, concomitant with increasing concentration of L-trp supplementation, appears to support the operation of an L-trp-dependent pathway for indole/IAA production by these bacterial isolates.

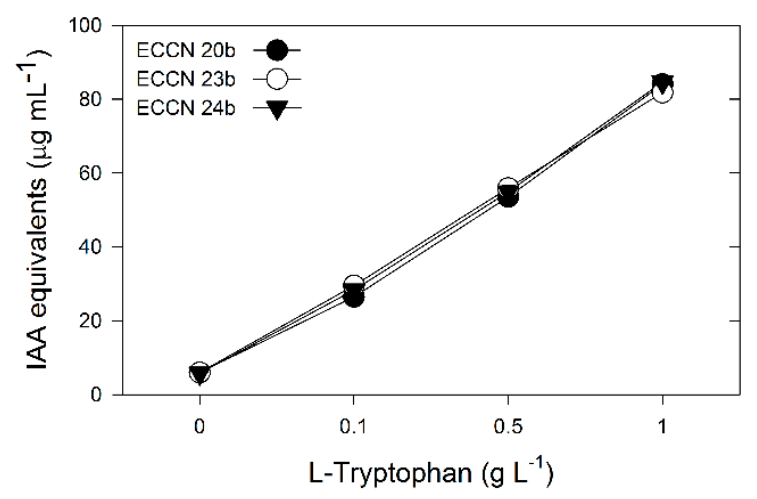

Figure 3. Indolic compound formation by cultures of Proteus ECCN 20b, Proteus ECCN 23b and Serratia ECCN 24b in response to increasing L-trp concentration. Results are from three experiments and expressed as the mean \pm S.E.

In view of the already established coal-biodegrading property of these strains, it was of interest to examine the effect of coal discard on production of indolic compounds by cultures of Proteus strain ECCN 20b, Proteus strain ECCN 23b and Serratia strain ECCN 24b. Increasing quantities of coal discard were supplied to these isolates in liquid culture and the effect on L-trp-supplemented indolic compound accumulation is shown in Figure 4.

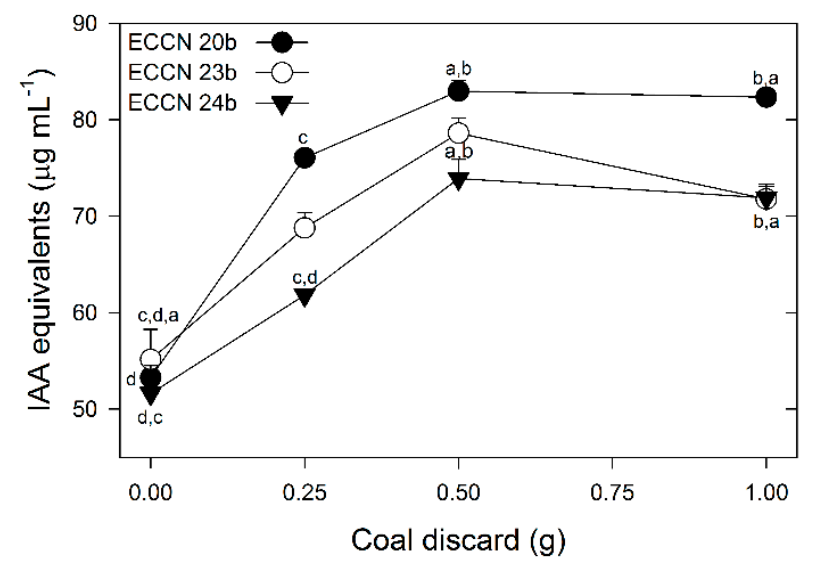

Figure 4. Effect of coal discard on formation of indolic compounds by cultures of Proteus ECCN 20b, Proteus ECCN 23b and Serratia ECCN 24b in response to L-trp supplementation. Results are from three experiments and expressed as the mean \pm S.E. Means denoted by a different letter indicate significant differences within treatments $(p<0.05)$. 
Typically, screening for production of IAA by putative PGP bacteria is carried out using an L-trp-supplemented medium [56,57]. Here, too, a L-trp-supplemented medium was used, and results show that in the presence of coal discard, production of indoles was enhanced for all three of the coal-degrading strains tested (Figure 4). In this experiment, coal was added to NB supplemented with L-trp at $0.5 \mathrm{~g} \mathrm{~L}^{-1}$. In the absence of coal discard, formation of indoles averaged $53.34 \mu \mathrm{g} \mathrm{mL}^{-1}$ IAA for the three strains tested, an observation that was similar to and corroborated initial screening studies (cf. Figure 2b). For strain ECCN 20b however, indole formation increased to 76.05, 82.96 and $82.33 \mu \mathrm{g} \mathrm{mL}^{-1}$ IAA in response to addition of $0.25,0.5$ and $1 \mathrm{~g}$ of coal discard, respectively (Figure 4 ). A similar, albeit less dramatic, response was observed for strains ECCN 23b and ECCN 24b. Indeed, coal discard above $0.5 \mathrm{~g}$ appeared to slow accumulation of indoles in all bacterial isolates tested. Maximum IAA was thus achieved in response to $0.5 \mathrm{~g}$-added coal discard, while competence for production of indolic compounds by these strains appeared to be ECCN 20b > ECCN 23b > ECCN 24b.

\section{Discussion}

Molecular ecological studies involve separation of amplicons based on differences in DNA nucleotide sequences and most often the $16 \mathrm{~S}$ rRNA gene, which can then be analysed from complex environments such as soil [58]. Databases thus generated yield invaluable information about indicator species [59]. To determine the phylogenetic relationship between coal-degrading bacteria isolated earlier [40] and the diverse array of PGP bacteria contained in the NCBI GenBank database, basic bioinformatics was used to determine the genetic relatedness of the 16S rRNA gene sequences while conventional biochemical assays were used to screen for putative PGP characteristics. Strains from seven genera of coal-degrading bacterial isolates utilised in the present study showed $\geq 99 \%$ homology with reference gene sequences of PGP bacteria contained in the NCBI GenBank database. $\mathrm{A}<1 \%$ deviation was attributed to the diversity of ecological niches from where the coal-degrading isolates and reference PGP strains were sourced.

Biochemical screening for traits typically associated with PGP showed that the most competent strains were those sourced from diesel-contaminated soil. These isolates were Proteus strain ECCN 20b, Proteus strain ECCN 23b and Serratia strain ECCN 24b. Interestingly, Serratia strain ECCN 24b, either alone or in consort with Citrobacter strain ECCN 19b and Exiguobacterium strain ECCN 21b, was previously shown to be most effective in coal bioconversion [40]. Furthermore, and in corroboration with results from other studies, Serratia strain ECCN $24 \mathrm{~b}$ was able to solubilise insoluble phosphate $[60,61]$ and potassium [62]. Recent studies have shown that the mineral-solubilising activity for promotion of plant growth is typically associated with the production of organic acids which, for strains of Serratia spp., appears to include gluconic and lactic acid [63].

In addition to the liberation of mineral nutrients, production of indolic compounds by Proteus strain ECCN 20b, Proteus strain ECCN 23b and Serratia strain ECCN 24b in L-trp-supplemented medium was substantial relative to the other coal-degrading bacterial isolates screened and increased linearly with an increase in L-trp concentration. Production of the plant hormone IAA and other indoles by bacteria is a long held and accepted view, in particular for microorganisms that inhabit subterranean plant surfaces [64-67]. Indeed, bacterial IAA biosynthesis can be either trp-dependent or independent [68] and results from the present study would seem to support the formation of indolic compounds by Proteus strain ECCN 20b, Proteus strain ECCN 23b and Serratia strain ECCN 24b via L-trp. Coal-degrading isolates that display a weak response to L-trp supplementation may either be non-responsive or produce indole by a trp-independent route. In higher plants like Arabidopsis thaliana and Zea mays, the major biosynthetic pathway to IAA is not via trp but seems to be from an earlier intermediate such as anthranilate [69]. Further, several studies have confirmed formation by bacteria of methyl anthranilate via chorismite in a single-step conversion of anthranilate to its methyl ester metabolite catalysed by an S-adenosyl-L-methionine (SAM)-dependent methyltransferase [70,71]. Whether a similar pathway operates in the coal-degrading strains that were unresponsive to L-trp supplementation in the present study is currently unknown. 
Additionally, exposure of Proteus strain ECCN 20b, Proteus strain ECCN 23b and Serratia strain ECCN $24 \mathrm{~b}$ to coal discard resulted in an apparent dose-dependent increase in the formation of indolic compounds. While indoles are a component of carbonised coal, e.g., coal tar and coke [72], and pyrolysates of Leonardite humic acids [73], they are not readily liberated from hard coal or coal discard, and in this study were undetectable in samples used to background correct for possible contribution to spectrophotometric quantitation using Salkowski's reagent.

In addition to the well-established PGP properties of Serratia spp. [74-77] and their ability to degrade the coal distillation product creosote [78], several promising PGP rhizobacterial strains of Proteus spp. have been isolated from the rhizosphere of rice [79-81], wild grass [82], a halophytic glasswort [83,84] and a nematocidal strain of P. penneri obtained from cow dung [85]. This genus was also relatively well represented (20\%) among the coal-degrading isolates utilised in this study and strains ECCN 20b and ECCN 23b, isolated from diesel-contaminated soil. There are numerous reports of hydrocarbon-degrading strains of Proteus spp. from soils [86-88], whereas, to our knowledge, the strains described here represent the first reported Proteus isolates with PGP potential capable of degrading coal. While there is reported evidence for isolation of Proteus spp. from diverse soil environments including isolates with heavy metals tolerance [89-91] and xenobiotic-degrading capability [92,93], no coal-degrading strains have been documented. However, at least one report indicates that a strain isolated from two different ranks of coal was unable to degrade lignin [94].

\section{Conclusions}

Our goal in the present study was to determine the genetic relatedness of coal-degrading bacterial strains isolated from the rhizosphere of grasses growing on coal discard dumps and from diesel-contaminated sites to sequences of known PGP isolates contained in the NCBI GenBank database. We then determined the potential functionality of this relatedness by screening for PGP characteristics. Analysis of PCR-amplified 16S rRNA gene sequences from the seven genera of coal-degrading bacteria showed $>99 \%$ homology to 32 sequences of known PGP strains from the NCBI GenBank database representing three families viz. four strains from each of the Bacilliaceae and Enterobacteriaceae and one strain from the Microbacteriaceae. The Gram-negative isolates Proteus strain ECCN 20b, Proteus strain ECCN 23b and Serratia strain ECCN 24b, all from Enterobacteriaceae and isolated from diesel-contaminated soil, were shown to be competent for PGP characteristics using the biochemical parameters described in this study. Thus, while all strains were competent for ammonium and indole compound production, and solubilisation of insoluble phosphate, only Proteus strain ECCN 20b, Proteus strain ECCN 23b and Serratia strain ECCN 24b responded to the L-trp-supplemented medium by substantial accumulation of indolic compounds. Further, for these strains, indole compound accumulation in response to L-trp supplementation was linear with increasing L-trp concentration and not negatively affected in the presence of coal discard. Even so, it remains to be determined whether bioconversion of coal can occur with simultaneous production of indole compounds and in particular the auxin, IAA.

Further screening is therefore needed to expand our knowledge of the suite of PGP properties of the coal-degrading isolates. Using a combination of genome mining and metabolomics, possible target characteristics could include auxin and siderophore production, nitrogen fixation and potential phyto-protective mechanisms. It is also important to determine any direct effect of the isolated PGP coal-degrading bacteria on plant growth and development. A better understanding of the plant-bacteria relation may lead eventually to candidate strains for the development of a biological process with which to treat, stabilise and even rehabilitate disturbed soils.

Author Contributions: Conceptualisation of the work was by A.K.C. and Y.T., methodology by A.K.C. and Y.T. while execution was by Y.T., W.L.M., and J.T.O.; validation, Y.T.; L.M.S.-D.; and W.L.M.; data curation, A.K.C.; writing-original draft preparation, Y.T. and A.K.C.; writing—review and editing, Y.T., A.K.C., L.M.S.-D.; J.T.O.; supervision, A.K.C.; project administration, A.K.C.; funding acquisition, A.K.C. All authors have read and agreed to the published version of the manuscript. 
Funding: This research was funded by Anglo Operations (Pty.) Ltd. (Anglo Coal), the National Research Foundation, South Africa (IFR1202220169, Grant No: 80879), and the Technology for Human Resources for Industry Programme (THRIP; TP13070820781, UID 90252).

Acknowledgments: Y.T. is supported by a Rhodes University Post-Doctoral Research Fellowship. W.L.M., and J.T.O. were supported by bursaries from EBRU. The authors are grateful to Rhodes University for additional financial support. Authors acknowledge the earlier bioprospecting work carried out by Lwazikazi Madikiza, Michelle Isaacs, and Gerald Edeki which led to the isolation and characterisation of the coal-degrading bacteria used in this study.

Conflicts of Interest: The authors declare no conflict of interest.

\section{References}

1. Fakoussa, R.M.; Hofrichter, M. Biotechnology and microbiology of coal degradation. Appl. Microbiol. Biotechnol. 1999, 52, 25-40. [CrossRef] [PubMed]

2. Machnikowska, H.; Pawelec, K.; Podgórska, A. Microbial degradation of low rank coals. Fuel Proc. Technol. 2002, 77, 17-23. [CrossRef]

3. Jiang, F.; Li, Z.; Lv, Z.; Gao, T.; Yang, J.; Qin, Z.; Yuan, H. The biosolubilization of lignite by Bacillus sp. Y7 and characterization of the soluble products. Fuel 2013, 103, 639-645. [CrossRef]

4. Speight, J.G. Handbook of Coal Analysis. In Chemical Analysis. A Series of Monographs on Analytical Chemistry and its Applications, 2nd ed.; Vitha, M.F., Ed.; John Wiley and Sons: Hoboken, NJ, USA, 2015; p. 368.

5. Claassens, S.; Van Rensburg, P.J.; Van Rensburg, L. Soil microbial community structure of coal mine discard under rehabilitation. Water Air Soil Pollut. 2006, 174, 355-366. [CrossRef]

6. Truter, W.J.; Rethman, N.F.G.; Potgieter, C.E.; Kruger, R.A. Re-vegetation of cover soils and coal discard material ameliorated with Class F fly ash. In Proceedings of the Collected Abstracts, 2009 World of Coal Ash (WOCA) Conference, Lexington, KY, USA, 4-7 May 2009; Available online: http://www.flyash.info/2009/110truter2009.pdf (accessed on 10 July 2020).

7. Sekhohola, M.L.; Igbinigie, E.E.; Cowan, A.K. Biological degradation and solubilisation of coal. Biodegradation 2013, 24, 305-318. [CrossRef]

8. Cowan, A.K.; Lodewijks, H.M.; Sekhohola, L.M.; Edeki, O.G. In situ bioremediation of South African coal discard dumps. In Proceedings of the 11th International Conference on Mine Closure, Perth, Australia, 15-17 March 2016; Fourie, A.B., Tibbett, M., Eds.; Australian Centre for Geomechanics: Perth, Western Australia, 2016; pp. 501-509.

9. Šourková, M.; Frouz, J.; Šantrucková, H. Accumulation of carbon, nitrogen and phosphorus during soil formation on alder spoil heaps after brown-coal mining, near Sokolov (Czech Republic). Geoderma 2005, 124, 203-214. [CrossRef]

10. Vindušková, O.; Frouz, J. Soil carbon accumulation after open-cast coal and oil shale mining in Northern Hemisphere: A quantitative review. Environ. Earth Sci. 2013, 69, 1685-1698. [CrossRef]

11. Sekhohola, L.M.; Cowan, A.K. Biological conversion of low-grade coal discard to a humic substance-enriched soil-like material. Int. J. Coal Sci. Technol. 2017, 4, 183-190. [CrossRef]

12. Ralph, J.P.; Catcheside, D.E.A. Transformations of low rank coal by Phanerochaete chrysosporium and other wood-rot fungi. Fuel Proc. Technol. 1997, 52, 79-93. [CrossRef]

13. Gotz, K.E.; Fakoussa, R.M. Fungal biosolubilization of Rhenish brown coal monitored by Curie-point pyrolysis/gas chromatography/mass spectrometry using tetraethylammonium hydroxide. Appl. Microbiol. Biotechnol. 1999, 52, 41-48. [CrossRef]

14. Gokcay, C.F.; Kolankaya, N.; Dilek, F.B. Microbial solubilization of lignites. Fuel 2001, 80, 1421-1433. [CrossRef]

15. Yuan, H.; Yang, J.; Chen, W. Production of alkaline materials, surfactants and enzymes by Penicillium decumbens strain P6 in association with lignite degradation/solubilization. Fuel 2006, 85, 1378-1382. [CrossRef]

16. Haider, R.; Ghauri, M.A.; SanFilipo, J.R.; Jones, E.J.; Orem, W.H.; Tatu, C.A.; Akhtar, K.; Akhtar, N. Fungal degradation of coal as a pretreatment for methane production. Fuel 2013, 104, 717-725. [CrossRef]

17. Kwiatos, N.; Jędrzejczak-Krzepkowska, M.; Krzemińska, A.; Delavari, A.; Paneth, P.; Bielecki, S. Evolved Fusarium oxysporum laccase expressed in Saccharomyces cerevisiae. Sci. Rep. 2020, 10, 3244. [CrossRef] [PubMed]

18. Kwiatos, N.; Jędrzejczak- Krzepkowska, M.; Strzelecki, B.; Bielecki, S. Improvement of efficiency of brown coal biosolubilization by novel recombinant Fusarium oxysporum laccase. AMB Express 2018, 8, 133. [CrossRef] [PubMed] 
19. Yang, Y.; Yang, J.; Li, B.; Wang, E.; Yuan, H. An esterase from Penicillium decumbens P6 involved in lignite depolymerization. Fuel 2018, 214, 416-422. [CrossRef]

20. Gao, T.G.; Jiang, F.; Yang, J.S.; Li, B.Z.; Yuan, H.L. Biodegradation of Leonardite an alkali-producing bacterial community and characterization of the degraded products. Appl. Microbiol. Biotechnol. 2012, 93, 2581-2590. [CrossRef]

21. David, Y.; Baylon, M.G.; Pamidimarri, S.D.V.N.; Baritugo, K.-A.; Chae, C.G.; Kim, Y.J.; Kim, T.W.; Kim, M.-S.; Na, J.G.; Par, S.J. Screening of microorganisms able to degrade low-rank coal in aerobic conditions: Potential coal biosolubilization mediators from coal to biochemicals. Biotechnol. Bioprocess Eng. 2017, 22, 178-185. [CrossRef]

22. Akimbekov, N.; Digel, I.; Qiaoa, X.; Tastambeka, K.; Zhubanova, A. Lignite biosolubilization by Bacillus sp. RKB 2 and characterization of its products. Geomicrobiol. J. 2020, 37, 255-261. [CrossRef]

23. Akimbekov, N.; Digel, I.; Abdieva, G.; Ualieva, P.; Tastambek, K. Lignite biosolubilization and bioconversion by Bacillus sp.: The collation of analytical data. Biofuels 2020. [CrossRef]

24. Lyle, G.; Whyte, L.; Charles, W.G. Biodegradation of petroleum hydrocarbons by psychrotrophic Pseudomonas strains possessing both alkane (alk) and naphthalene (nah) catabolic pathways. Appl. Environ. Microbiol. 1997, 63, 3719-3723.

25. Jiang, B.; Zhou, Z.; Dong, Y.; Tao, W.; Wang, B.; Jiang, J.; Guan, X. Biodegradation of benzene, toluene, ethylbenzene, and $o_{-}, m_{-}$, and $p$-xylenes by the newly isolated bacterium Comamonas sp. Appl. Biochem. Biotechnol. 2015, 176, 1700-1708. [CrossRef] [PubMed]

26. Truskewycz, A.; Gundry, T.D.; Khudur, L.S.; Kolobaric, A.; Taha, M.; Aburto-Medina, A.; Ball, A.S.; Shahsavari, E. Petroleum hydrocarbon contamination in terrestrial ecosystems-Fate and microbial responses. Molecules 2019, 24, 3400. [CrossRef]

27. Lee, Y.; Lee, Y.; Jeon, C.O. Biodegradation of naphthalene, BTEX, and aliphatic hydrocarbons by Paraburkholderia aromaticivorans BN5 isolated from petroleum-contaminated soil. Sci. Rep. 2019, 9, 860. [CrossRef] [PubMed]

28. Khan, S.; Afzal, M.; Iqbal, S.; Khan, Q.M. Plant-Bacteria partnerships for the remediation of hydrocarbon contaminated soils. Chemosphere 2013, 90, 1317-1332. [CrossRef]

29. Yu, Y.; Zhang, Y.; Zhao, N.; Guo, J.; Xu, W.; Ma, M.; Li, X. Remediation of crude oil-polluted soil by the bacterial rhizosphere community of Suaeda Salsa revealed by $16 \mathrm{~S}$ rRNA genes. Int. J. Environ. Res. Public Health 2020, 17, 1471. [CrossRef]

30. Silva-Stenico, M.E.; Vengadajellum, C.J.; Janjua, H.A.; Harisson, S.T.L.; Burton, S.G.; Cowan, D.A. Degradation of low rank coal by Trichoderma atroviride ES11. J. Ind. Microbiol. Biotechnol. 2007, 34, 625-631. [CrossRef]

31. Romanowska, I.; Strzelecki, B.; Bielecki, S. Biosolubilization of Polish brown coal by Gordonia alkanivorans S7 and Bacillus mycoides NS1020. Fuel Proc. Technol. 2015, 131, 430-436. [CrossRef]

32. Valero, N.; Gómez, L.; Pantoja, M.; Ramírez, R. Production of humic substances through coal-solubilizing bacteria. Braz. J. Microbiol. 2014, 45, 911-918. [CrossRef]

33. Strapoć, D.; Mastalerz, M.; Dawson, K.; Macalady, J.; Callaghan, A.V.; Wawrik, B.; Turich, C.; Ashby, M. Biogeochemistry of microbial coal-bed methane. Annu. Rev. Earth Pl. Sci. 2011, 39, 617-656. [CrossRef]

34. Huang, Z.; Urynowicz, M.A.; Colberg, P.J.S. Bioassay of chemically treated subbituminous coal derivatives using Pseudomonas putida F1. Int. J. Coal Geol. 2013, 115, 97-105. [CrossRef]

35. Jones, E.J.P.; Voytek, M.A.; Warwick, P.D.; Corum, M.D.; Cohn, A.; Bunnel, J.E.; Clark, A.C.; Orem, W.H. Bioassay for estimating the biogenic methane generating potential of coal samples. Int. J. Coal Geol. 2008, 76, 138-150. [CrossRef]

36. Yin, S.; Tao, X.; Shi, K.; Tan, Z. Biosolubilisation of Chinese lignite. Energy 2009, 34, 775-781. [CrossRef]

37. Barboza, N.R.; Amorim, S.S.; Santos, P.A.; Reis, F.D.; Cordeiro, M.M.; Guerra-Sá, R.; Leão, V.A. Indirect manganese removal by Stenotrophomonas sp. and Lysinibacillus sp. isolated from Brazilian mine water. Biomed. Res. Int. 2015, 2015, 925972. [CrossRef] [PubMed]

38. Barboza, N.R.; Morais, M.M.C.A.; Queiroz, P.S.; Amorim, S.S.; Guerra-Sá, R.; Leão, V.A. High manganese tolerance and biooxidation ability of Serratia marcescens isolated from manganese mine water in Minas Gerais, Brazil. Front. Microbiol. 2017, 8, 1946. [CrossRef] [PubMed]

39. Ibrahim, H.M.M. Biodegradation of used engine oil by novel strains of Ochrobactrum anthropi HM-1 and Citrobacter freundii HM-2 isolated from oil-contaminated soil. 3 Biotech. 2016, 6, 226. [CrossRef] 
40. Olawale, J.T.; Edeki, O.G.; Cowan, A.K. Bacterial degradation of coal discard and geologically weathered coal. Int. J. Coal Sci. Technol. 2020, 7, 405-416. [CrossRef]

41. Santoyo, G.; Moreno-Hagelsieb, G.; del Carmen Orozco-Mosqued, M.; Glick, B.R. Plant growth-promoting bacterial endophytes. Microbiol. Res. 2016, 183, 92-99. [CrossRef]

42. Lane, D.J. 16S/23S rRNA sequencing. In Nucleic acid Techniques in Bacterial Systematics; Stackebrandt, E., Goodfellow, M., Eds.; John Wiley \& Sons: New York, NY, USA, 1991; pp. 115-175.

43. Turner, S.J.; Pryer, K.M.; Miao, V.P.M.; Palmer, J.D. Investigating deep phylogenetic relationships among cyanobacteria and plastids by small subunit rRNA sequence analysis. J. Eukaryot. Microbiol. 1999, 46, 327-338. [CrossRef]

44. Technelysium (Chromas). Available online: http://www.technelysium.com.auu/chromas.html (accessed on 18 May 2019).

45. Hall, T.A. BioEdit: A user-friendly biological sequence alignment editor and analysis program for Windows 95/98/NT. Nucl. Acids Symp. Ser. 1999, 41, 95-98.

46. Tamura, K.; Stecher, G.; Peterson, D.; Filipski, K.; Kumar, S. Molecular evolutionary genetic analysis version 6.0. Mol. Biol. Evol. 2013, 30, 2725-2729. [CrossRef] [PubMed]

47. Jeong, H.; Park, J.; Kim, H. Determination of $\mathrm{NH}_{4}{ }^{+}$in environmental water with interfering substances using the modified Nessler method. J. Chem. 2013, e359217. [CrossRef]

48. Gordon, S.A.; Weber, R.P. Colorimetric estimation of indoleacetic acid. Plant Physiol. 1951, 26, $192-195$. [CrossRef] [PubMed]

49. Glickmann, E.; Dessaux, Y. A critical examination of the specificity of the Salkowski reagent for indolic compounds produced by phytopathogenic bacteria. Appl. Environ. Microbiol. 1995, 61, 793-796. [CrossRef]

50. Majeed, A.; Abbasi, M.K.; Hameed, S.; Imran, A.; Rahim, N. Isolation and characterization of plant growth-promoting rhizobacteria from wheat rhizosphere and their effect on plant growth promotion. Front. Microbiol. 2015, 6, 198. [CrossRef]

51. Sharma, S.B.; Sayyed, R.Z.; Trivedi, M.H.; Gobi, T.A. Phosphate solubilising microbes: Sustainable approach for managing phosphorus deficiency in agricultural soils. SpringerPlus 2013, 2, 587. [CrossRef]

52. Saha, M.; Maurya, B.R.; Meena, V.S.; Bahadur, I.; Kumar, A. Identification and characterisation of potassium solubilising bacteria (KSB) from Indo-Gangetic Plains of India. Biocatal. Agric. Biotechnol. 2016, 7, 202-209. [CrossRef]

53. Pflaum, R.T.; Howick, L.C. Spectrophotometric determination of potassium with sodium tetraphenyl-borate. Anal. Chem. 1956, 28, 1542-1544. [CrossRef]

54. Bechtaoui, N.; Raklami, A.; Tahiri, A.-I.; Benidire, L.; El Alaoui, A.; Meddich, A.; Gottfert, M.; Oufdou, K. Characterization of plant growth promoting rhizobacteria and their benefits on growth and phosphate nutrition of faba bean and wheat. Biol. Open 2019, 8, bio043968. [CrossRef]

55. Patten, C.L.; Blakney, A.J.C.; Coulson, T.J.D. Activity, distribution and function of indole-3-acetic acid biosynthetic pathways in bacteria. Crit. Rev. Microbiol. 2013, 39, 395-415. [CrossRef]

56. Tien, T.M.; Gaskins, M.H.; Hubbell, D.H. Plant growth substances produced by Azospirillum brasilense and their effect on the growth of pearl millet (Pennisetum americanum L.). Appl. Environ. Microbiol. 1979, 37, 1016-1024. [CrossRef] [PubMed]

57. Marappa, N.; Ramachandran, L.; Dharumadurai, D.; Nooruddin, T. Plant growth-promoting active metabolites from Frankia spp. of Actinorhizal Casuarina spp. Appl. Biochem. Biotechnol. 2020, 191, 74-91. [CrossRef] [PubMed]

58. Throbäck, I.N.; Enwall, K.; Jarvis, A.; Hallin, S. Reassessing PCR primers targeting nirS, nirK and nosZ genes for community surveys of denitrifying bacteria with DGGE. FEMS Microbiol. Ecol. 2004, 49, 401-417. [CrossRef] [PubMed]

59. Reynolds, K.A.; Surridge, A.K.J. Ash microbiology: A molecular study. In Proceedings of the Collected Abstracts, 2009 World of Coal Ash (WOCA) Conference, Lexington, KY, USA, 4-7 May 2009; Available online: http://www.flyash.info/2009/031-surridge2009.pdf (accessed on 10 July 2020).

60. Chen, Y.P.; Rekha, P.D.; Arun, A.B.; Shen, F.T.; Lai, W.A.; Young, C.C. Phosphate solubilizing bacteria from subtropical soil and their tricalcium phosphate solubilizing abilities. Appl. Soil Ecol. 2006, 34, 33-41. [CrossRef] 
61. Farhat, M.B.; Farhat, A.; Bejar, W.; Kammoun, R.; Bouchaala, K.; Fourati, A.; Antoun, H.; Bejar, S.; Chouayekh, H. Characterization of the mineral phosphate solubilizing activity of Serratia marcescens CTM 50650 isolated from the phosphate mine of Gafsa. Arch. Microbiol. 2009, 191, 815-824. [CrossRef]

62. Mursyida, E.; Mubarik, N.R.; Tjahjoleksono, A. Selection and identification of phosphate-potassium solubilizing bacteria from the area around the limestone mining in Cirebon Quarry. Res. J. Microbiol. 2015, 10, 270-279.

63. Borgi, M.A.; Saidi, I.; Moula, A.; Rhimi, S.; Rhimi, M. The attractive Serratia plymuthica BMA1 strain with high rock phosphate-solubilizing activity and its effect on the growth and phosphorus uptake by Vicia faba L. plants. Geomicrobiol. J. 2020, 37, 437-445. [CrossRef]

64. Wichner, S.; Libbert, E. Interactions between plants and epiphytic bacteria regarding their auxin metabolism. I. Detection of IAA-producing epiphytic bacteria and their role in long duration experiments on tryptophan metabolism in plant homogenates. Physiol. Plant. 1968, 21, 227-241. [CrossRef]

65. Fett, W.F.; Osman, S.F.; Dunn, M.F. Auxin production by plant-pathogenic Pseudomonads and Xanthomonads. Appl. Environ. Microbiol. 1987, 53, 1839-1845. [CrossRef]

66. Patten, C.L.; Glick, B.R. Bacterial biosynthesis of indole-3-acetic acid. Can. J. Microbiol. 1996, 42, $207-220$. [CrossRef]

67. Zarkan, A.; Liu, J.; Matuszewska, M.; Gaimster, H.; Summer, D.K. Local and universal action: The paradoxes of indole signalling in bacteria. Trends Microbiol. 2020, 28, 566-577. [CrossRef] [PubMed]

68. Duca, D.; Lorv, J.; Patten, C.L.; Rose, D.; Glick, B.R. Indole-3-acetic acid in plant-microbe interactions. Antonie Van Leeuwenhoek 2014, 106, 85-125. [CrossRef] [PubMed]

69. Normanly, J.; Cohen, J.D.; Fink, G.R. Arabidopsis thaliana auxotrophs reveal a tryptophan-independent biosynthetic pathway for indole-3-acetic acid. Proc. Natl. Acad. Sci. USA 1993, 90, 10355-10359. [CrossRef] [PubMed]

70. Taupp, M.; Harmsen, D.; Heckel, F.; Schreier, P. Production of natural methyl anthranilate by microbial $\mathrm{N}$-demethylation of N-methyl methyl anthranilate by the topsoil-isolated bacterium Bacillus megaterium. J. Agric. Food Chem. 2005, 53, 9586-9589. [CrossRef] [PubMed]

71. Luo, Z.W.; Cho, J.S.; Lee, S.Y. Microbial production of methyl anthranilate, a grape flavor compound. Proc. Natl. Acad. Sci. USA 2019, 116, 10749-10756. [CrossRef]

72. Kölling, G. Products of coal (coke, tar, gas) and their analysis. Pure Appl. Chem. 1977, 49, 1475-1482. [CrossRef]

73. Stefanova, M.; Gonsalvesh, L.; Marinov, S.P.; Czech, J.; Carleer, R.; Yperman, J. Reductive pyrolysis of leonardite humic acids. Bulg. Chem. Commun. 2014, 46, 123-128.

74. Grimont, P.A.D.; Grimont, F. The genus Serratia. Annu. Rev. Microbiol. 1978, 32, 221-248. [CrossRef]

75. Singh, R.P.; Jha, P.N. The multifarious PGPR Serratia marcescens CDP-13 augments induced systemic resistance and enhanced salinity tolerance of wheat (Triticum aestivum L.). PLoS ONE 2016, 11, e0155026. [CrossRef]

76. Khan, A.R.; Park, G.-S.; Asaf, S.; Hong, S.-J.; Jung, B.K.; Shin, S.-H. Complete genome analysis of Serratia marcescens RSC-14: A plant growth-promoting bacterium that alleviates cadmium stress in host plants. PLoS ONE 2017, 12, e0171534. [CrossRef]

77. Matteoli, F.P.; Passarelli-Araujo, H.; Reis, R.J.A.; da Rocha, L.O.; de Souza, E.M.; Aravind, L.; Olivares, F.L.; Venancio, T.M. Genome sequencing and assessment of plant growth-promoting properties of a Serratia marcescens strain isolated from vermicompost. BMC Genom. 2018, 19, 750. [CrossRef] [PubMed]

78. Smułek, W.; Sydow, M.; Zabielska-Matejuk, J.; Kaczorek, E. Bacteria involved in biodegradation of creosote PAH-A case study of long-term contaminated industrial area. Ecotox. Environ. Saf. 2020, 187, 109843. [CrossRef] [PubMed]

79. Das, A.C.; Mukherjee, D. Soil application of insecticides influences microorganisms and plant nutrients. Appl. Soil Ecol. 2000, 14, 55-62. [CrossRef]

80. Das, A.C.; Chakravarty, A.; Sukul, P.; Mukherjee, D. Insecticides: Their effect on microorganisms and persistence in rice soil. Microbiol. Res. 1995, 150, 187-194. [CrossRef]

81. Das, A.C.; Chakravarty, A.; Sukul, P.; Mukherjee, D. Influence and persistence of phorate and carbofuran insecticides on microorganisms in rice field. Chemosphere 2003, 53, 1033-1037. [CrossRef]

82. Rau, N.; Mishra, V.; Sharma, M.; Das, M.K.; Ahaluwalia, K.; Sharma, R.S. Evaluation of functional diversity in Rhizobacterial taxa of a wild grass (Saccharum ravennae) colonizing abandoned fly ash dumps in Delhi urban ecosystem. Soil Biol. Biochem. 2009, 41, 813-821. [CrossRef] 
83. Yu, S.M.; Lee, Y.H. Plant growth promoting rhizobacterium Proteus vulgaris JBLS202 stimulates the seedling growth of Chinese cabbage through indole emission. Plant Soil 2013, 370, 485-495. [CrossRef]

84. Bhattacharyya, D.; Garladinne, M.; Lee, Y.H. Volatile indole produced by rhizobacterium Proteus vulgaris JBLS202 stimulates growth of Arabidopsis thaliana through auxin, cytokinin, and brassinosteroid pathways. J. Plant Growth Regul. 2015, 34, 158-168. [CrossRef]

85. Lu, H.; Wang, X.; Zhang, K.; Lu, Y.; Zhou, L.; Li, G. Identification and nematicidal activity of bacteria isolated from cow dung. Ann. Microbiol. 2014, 64, 407-411. [CrossRef]

86. Hernandez-Rivera, M.A.; Ojeda-Morales, M.E.; Martinez-Vazquez, J.G.; Villegas-Cornelio, V.M.; Cordova-Bautista, Y. Optimal parameters for in vitro development of the hydrocarbonoclastic microorganism Proteus sp. J. Soil Sci. Plant Nutr. 2011, 11, 29-43. [CrossRef]

87. Ibrahim, M.L.; Ijah, U.J.J.; Manga, S.B.; Bilbis, L.S.; Umar, S. Production and partial characterization of biosurfactant produced by crude oil degrading bacteria. Int. Biodeterior. Biodegrad. 2013, 81, 28-34. [CrossRef]

88. Obayori, O.S.; Salam, L.B.; Oyetibo, G.O.; Idowu, M.; Amund, O.O. Biodegradation potentials of polyaromatic hydrocarbon (pyrene and phenanthrene) by Proteus mirabilis isolated from an animal charcoal polluted site. Biocatal. Agric. Biotechnol. 2017, 12, 78-84. [CrossRef]

89. Hassen, A.; Saidi, N.; Cherif, M.; Boudabous, A. Resistance of environmental bacteria to heavy metals. Bioresour. Technol. 1998, 64, 7-15. [CrossRef]

90. Ge, S.; Dong, X.; Zhou, J.; Ge, S. Comparative evaluations on bio-treatment of hexavalent chromate by resting cells of Pseudochrobactrum sp. and Proteus sp. in wastewater. J. Environ. Manag. 2013, 126, 7-12. [CrossRef] [PubMed]

91. Islam, F.; Yasmeen, T.; Riaz, M.; Arif, M.S.; Ali, S.; Raza, S.H. Proteus mirabilis alleviates zinc toxicity by preventing oxidative stress in maize (Zea mays) plants. Ecotoxicol. Environ. Saf. 2014, 110, 143-152. [CrossRef]

92. Olukanni, O.D.; Osuntoki, A.A.; Kalyani, D.C.; Gbenle, G.O.; Govindw, S.P. Decolorization and biodegradation of Reactive Blue 13 by Proteus mirabilis LAG. J. Hazard Mater. 2010, 184, 290-298. [CrossRef]

93. Pino, N.J.; Dominguez, M.C.; Peňuela, G.A. Isolation of a selected microbial consortium capable of degrading methyl parathion and p-nitrophenol from a contaminated soil site. J. Environ. Sci. Heal. B 2011, 46, 173-180. [CrossRef]

94. Wang, L.; Nie, Y.; Tang, Y.-Q.; Song, X.-M.; Cao, K.; Sun, L.-Z.; Wang, Z.-J.; Wu, X.-L. Diverse bacteria with lignin degrading potentials isolated from two ranks of coal. Front. Microbiol. 2016, 7, 1428. [CrossRef]

(C) 2020 by the authors. Licensee MDPI, Basel, Switzerland. This article is an open access article distributed under the terms and conditions of the Creative Commons Attribution (CC BY) license (http://creativecommons.org/licenses/by/4.0/). 